\title{
The Factors That Influence to Indonesian Consumers to Purchase Korean Halal Food
}

\author{
Lee Jongho $^{1}$, Sri Rahayu Hijrah Hati ${ }^{2}$ \\ cutycu@naver.com \\ Universitas Indonesia
}

\begin{abstract}
In this study, we suggest the basis and marketing plan to expand the expert of Korean food, especially Indonesia consumer, by improving understanding of Halal industry and consumer awareness in Indonesia and providing information on Halal certification issue. Suggesting ways to strengthen the credibility of Halal certification in Korea and seek to build trust between the two countries through the food industry. This paper develops a nine-constructs-based model. Halal awareness, Awareness of Korea, Religious Belief, Halal logo, Exposure, $\mathrm{COO}$ credibility, Islamic brand and product ingredients are used as the pre-determined factors for measuring consumer's purchase intention. This study suggests that the higher the understanding of Korea, the higher the reliability of Korean-produced Halal-certified foods. In other words, promoting Korea, spreading Korean food, and providing a positive image means that the Halal products exported from Korea can be made more reliable. Consumers are aware of the by products derived from the issues they are familiar with, especially those products that are trusted to provide the prescribed standards. Also Religious belief, Halal awareness, Product ingredient have a positive impact on the purchasing intention. This research is expected to have theoretical and practical contributions in both academic society and practitioners, especially to the one who involved in food industry.
\end{abstract}

Keywords: Halal, Awareness of Korea, Halal Certification, Country of Origin, TPB, Marketing, Strategy, Product Intention, Halal Awareness,

\section{INTRODUCTION}

Internationally, many developed and emerging economies are investing in new markets to escape from the current market, which is becoming saturated in the 21 st century. Among them, the research on the Muslim market, which has been perceived to be unrecognized up to now, is on the rise and shows a positive prospect of the potential value of the Muslim market. The Halal industry is rapidly emerging as a new $\$ 2$ trillion industry, but it is still a positive outlook for the Muslim market, is a child step (Korea Trade Investment Promotion Agency's 2010).

The Muslim population, geographically distributed in many parts of the world, is perceived as a gigantic consumer market of 1.6 billion people with a religious homogeneity of the country. Apart from the prejudice of a male-centered society with a closed and ascetic image of the past, countries such as Southeast Asia, Indonesia, Malaysia and the Arab countries of Egypt, Algeria and Saudi Arabia are expanding market openness to other cultures. The reasons for this change are the abundance of resource-based economic power, high population growth rate, and strong consumption patterns, as well as the widening of the upper middle class due to income growth ( Focus 2011) 
Halal market in Indonesia, many institutions and companies are actively investing in and researching the new frontier market of Halal industry. However, in light of the potential of Korea in comparison with other advanced and multinational companies, the recognition of Halal market and Halal certification are still less than those of other competitors in the international market. It is lagging behind in all areas, from basic market concepts to economics.

\section{REASERCH METHODOLOGY}

\subsection{Research Design}

The purpose of this study was to investigate the related factors influencing the intention of halal food purchasing for Muslims who design a research model and occupy the majority of Indonesian population, And to draw up hypotheses for research.

A research model has been created to carry out this study based on various existing literature on Halal-certified food purchasing factors and consumer behavior. The variables obtained from previous studies and theoretical considerations are as follows.

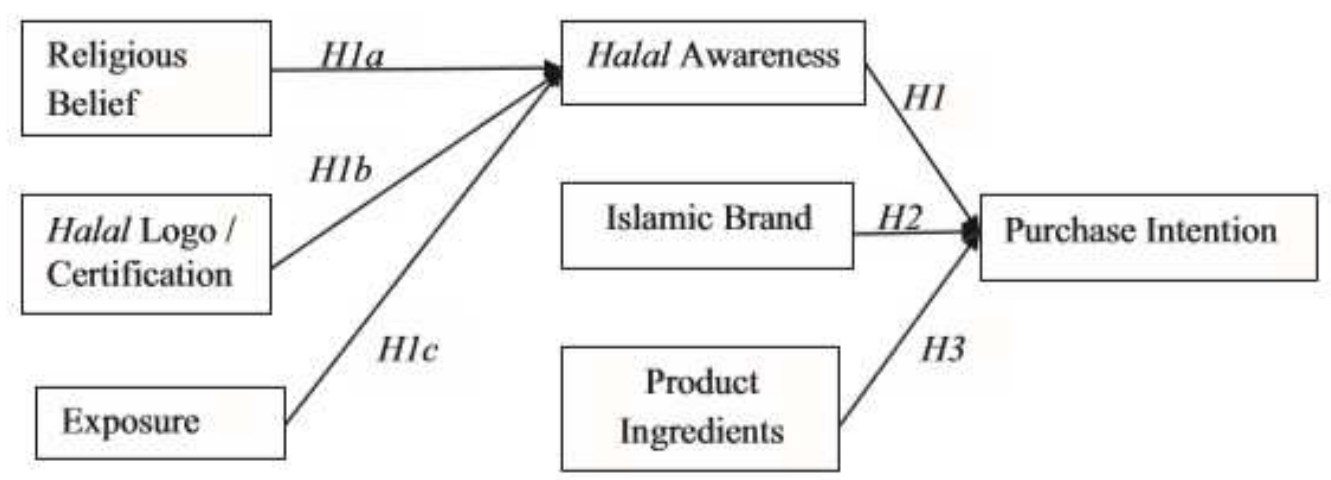

Figure. 1. Source : Afshan Azam, (2016) "An empirical study on non-Muslim's packaged halal food manufacturers

According to the study of Afshan Azam, The research framework for this study (Figureure 3.1 ) is adapted from the theory of planned behaviour (TPB; Ajzen, 1991). TPB is an established motivation-based model originated from Fischbein's Expectancy Theory (Ajzen, 1991). TPB model argues that ones' behavioural action is strongly determined by their behavioural intention, while the latter is the product of ones' attitude towards a particular behaviour, perceived others' expectations on the behaviour,and ones' perceived control over the behaviour(Ajzen,1991). Severalmeta analyses and model comparison studies support the high efficacy of the modelin predicting accuracy of behavioural intention and reported 
behaviours (Lajunen and Räsänen, 2004; SandbergandConner,2008). This study incorporates: a construct of the importance of $\mathrm{COO}$ in assessing credibility of a halallogo; and areligiosity construct. The combination of these two constructs helps to understand consumers' decisionmaking relying on halallogos through a theoretical framework of $\mathrm{COO}$ and religious influence.

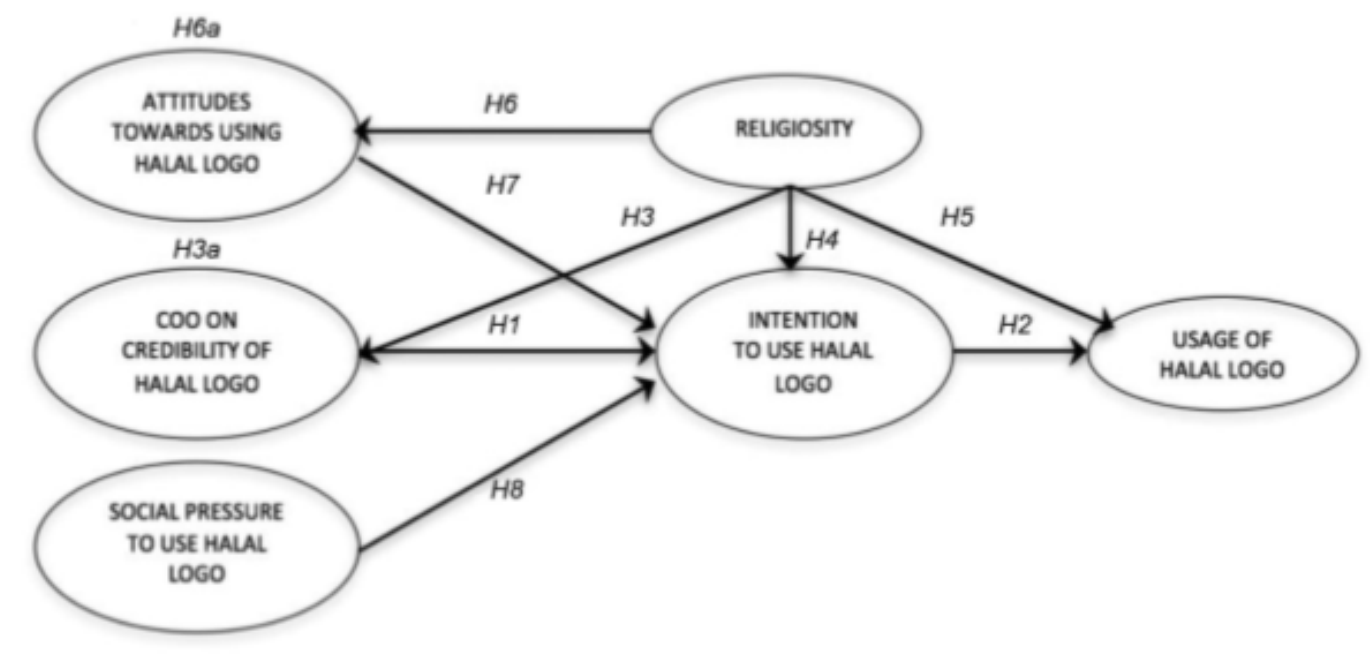

Figure. 2. Source : Nazlida Muhamad and VaiShiem Leong(2017)Does the country of origin of a halallogo matter? The case of packaged food purchases

We have also cited the above structural model to analyze the impact of other factors. To conduct this study, halal awareness, Islamic brand and product ingredients functioned as the three mainin dependent variables as input in determining its influence toward the dependent variable. On the other hand, purchase intention has been labeled as the dependent variable, as most of the discussion in the literature review illustrates that those listed independent variables have been widely used as pre-assumptions to prove its relationship.Therefore,this study proposes the following framework, whichis illustrated in Figureure3.2

\subsection{Hypothesis}

This study examined the effects of Korean Awarenesss, Religious beliefs, Halal logo, and Exposure effects on Halal Awareness and Credibility of COO, and investigated the effect of these factors on the intention to buy food in Indonesia Muslims Several hypotheses have been written based on the above study model. 
* Hypothesis 1 :

Awareness of Korea has a positive impact on the credibility of Halal-certified

* Hypothesis $2 A$ :

Religious belief has a positive impact on the belief that COO of Halal logo indicates Halal logo's credibility.

* Hypothesis $2 B$ :

Religious belief of Muslims has a positive impact on level of awareness toward Halal foods or products among Muslims.

* Hypothesis 3 :

Halal certification/logo enforcement has a positive impact on level of awareness toward Halal foods product from Korea among Muslims

* Hypothesis 4 :

Exposure through advertisements and teaching has a positive impact on level of awareness toward Halal foods product from Korea among Muslims.

* Hypothesis 5 :

The belief that a Halal logo COO indicates the credibility of the logo is positively related to the intention to consider a Halal logo during a food product from Korea purchase.

* Hypothesis 6 :

Halal awareness has a positive impact on a Muslim's intention to purchase a non-Muslim's Halal food

* Hypothesis 7 :

Islamic brand has a positive impact on a Muslim's intention to purchase a Halal food.

* Hypothesis 8 :

Product ingredients have a positive impact on a Muslim's intention to purchase a nonMuslim Halal food 


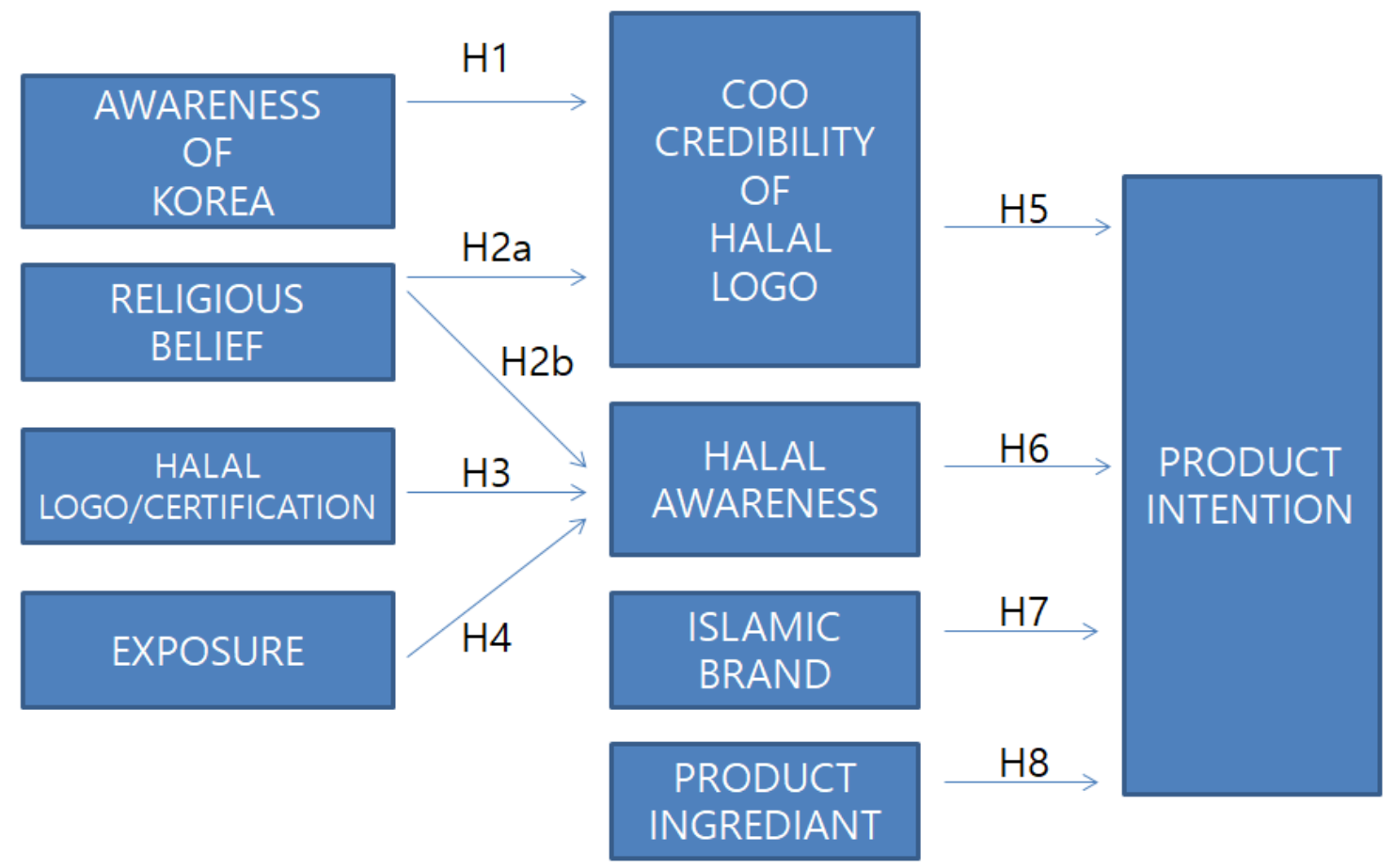

\section{ANALYSIS AND DISCUSSION.}

\subsection{Confirmatory Factor Analysis \& Reliability Analysis}

In this study, we used the method of evaluating the reliability of the measurement concept consisting of several items by using the Cronbach's alpha coefficient, which is commonly used to measure the reliability, Or 0.7 or better, and thus 0.6 was selected as the evaluation criterion in this study.

This study validated the dimensional validity through Confirmatory Factor Analysis (CFA) as a method to verify the validity. Average Variance Extracted (AVE) and Composite Construct Reliability (CCR) The results of this study are summarized as follows.

The validity of discrimination was verified through correlation analysis. This study used Cronbach's $\alpha \geq 0.7$ criterion to identify the internal consistency, and confirmatory factor analysis was $\chi^{2}(\mathrm{p} \geq 0.05), \mathrm{CMIN} / \mathrm{df} \leq 3, \mathrm{CFI} \geq 0.9$, RMSEA $\leq 0.08, \mathrm{RMR} \leq 0.08, \mathrm{NFI} \geq 0.9$, and $T L I \geq 0.9$ were used. 
In order to verify the convergent validity, we used the criteria of factor load of 0.4 or more, AVE (average variance extraction) of 0.5 or more and CCR (conceptual reliability) of 0.7 or more. Finally, in order to verify the discriminant validity, it is evaluated that the discriminant validity is obtained when the AVE value is larger than the correlation value between the latent variables.

It is called reliability verification or Cronbach alpha verification to see if it is possible to obtain the same measurement value if the measurement is repeated for the same concept. In a normal paper, it is judged that reliability is 0.6 or more.

\subsection{Confirmatory Factor Analysis of All Research Models (CFA)}

In this study, Confirmatory Factor Analysis (CFA) was conducted to evaluate the validity of factor structure and measurement model for measurement tools. Confirmatory factor analysis is used to test the validity of measurement tools such as intensive validity and discriminant validity as an analytical method for verifying the relationship between latent variables and observed variables and potential variables. The validity of $\chi 2$, GFI, AGFI, CFI, RMR To determine the model fit.

The validity and validity of the measurement model were verified through confirmatory factor analysis. As shown in $<$ Table 4-2>, the fitness of the measurement model was $\chi 2 / \mathrm{df}=$ 2.137 (standard $<0.3$ ), RMR was 0.051 and less than 0.08 , and GFI was 0.851 , which was close to the standard value of 0.9 can do. Also, as a result of the CFI analysis, the fitness index of 0.927 was found to be 0.9 or more, which is the standard value, and RMSEA is 0.057 , which is smaller than 0.08 .

Confirmatory factor analysis of the whole research model

\begin{tabular}{c|c|c|c|c|c|c}
\hline Factor & Variable & Estimate & S.E & CCR & AVE & Cronbach alpa \\
\hline \hline & & & & & & \\
& & & & & & \\
AWARENESS OF KOREA 1 & 0.588 & & & & \\
KOREA & AWARENESS OF KOREA 2 & 0.604 & 0.100 & & & \\
& AWARENESS OF KOREA 3 & 0.598 & 0.114 & 0.854 & 0.500 & 0.827 \\
& AWARENESS OF KOREA 4 & 0.664 & 0.128 & & & \\
& AWARENESS OF KOREA 5 & 0.913 & 0.119 & & & \\
& AWARENESS OF KOREA 6 & 0.636 & 0.135 & & & \\
& & & & & & \\
\hline RELIGIUOS BELIEFE & RELIGIUOS BELIEFE 1 & \multicolumn{2}{|c|}{ Delete } & 0.845 & 0.659 & 0.749 \\
\hline
\end{tabular}




\begin{tabular}{|c|c|c|c|c|c|c|}
\hline & $\begin{array}{l}\text { RELIGIUOS BELIEFE } 2 \\
\text { RELIGIUOS BELIEFE } 3 \\
\text { RELIGIUOS BELIEFE } 4\end{array}$ & $\begin{array}{l}0.519 \\
0.983 \\
0.752\end{array}$ & $\begin{array}{l}0.256 \\
0.226\end{array}$ & & & \\
\hline \multirow{4}{*}{$\begin{array}{c}\text { HALAL } \\
\text { LOGO/CERTIFICATION }\end{array}$} & HALALLOG/GRIFCATION1 & 0.782 & & \multirow{5}{*}{0.768} & \multirow{5}{*}{0.539} & \multirow{4}{*}{0.703} \\
\hline & HALALLOG/GRITCATION2 & 0.803 & 0.103 & & & \\
\hline & HALALLOGO/GRIIRCATION3 & \multicolumn{2}{|c|}{ Delete } & & & \\
\hline & HALALLOGO/GRIIHCATION4 & 0.448 & 0.097 & & & \\
\hline Factor & Variable & Estimate & S.E & & & Cronbach alpa \\
\hline \multirow[t]{3}{*}{ EXPOSURE } & \multirow{3}{*}{$\begin{array}{l}\text { EXPOSURE } 1 \\
\text { EXPOSURE } 2 \\
\text { EXPOSURE } 3 \\
\text { EXPOSURE } 4\end{array}$} & $\begin{array}{l}0.998 \\
0.713\end{array}$ & 0.062 & \multirow[t]{3}{*}{0.863} & \multirow[t]{3}{*}{0.69} & \multirow[t]{3}{*}{0.774} \\
\hline & & \multicolumn{2}{|c|}{ Delete } & & & \\
\hline & & 0.562 & 0.081 & & & \\
\hline $\begin{array}{c}\text { COO CREDIBILTY OF } \\
\text { HALAL LOGO }\end{array}$ & $\begin{array}{l}\text { COO CREDIBILTY OF } \\
\text { HALAL LOGO1 } \\
\text { COO CREDIBILTY OF } \\
\text { HALAL LOGO2 } \\
\text { COO CREDIBILTY OF } \\
\text { HALAL LOGO3 }\end{array}$ & $\begin{array}{l}0.521 \\
0.978 \\
0.504\end{array}$ & $\begin{array}{l}0.419 \\
0.299\end{array}$ & 0.789 & 0.58 & 0.723 \\
\hline \multirow{3}{*}{ HALAL AWARENESS } & HALAL AWARENESS 1 & 0.705 & & \multirow{3}{*}{0.839} & \multirow{3}{*}{0.726} & \multirow{3}{*}{0.789} \\
\hline & HALAL AWARENESS 2 & 0.913 & 0.227 & & & \\
\hline & HALAL AWARENESS 4 & \multicolumn{2}{|c|}{ Delete } & & & \\
\hline ISLAMIC BRAND & $\begin{array}{l}\text { ISLAMIC BRAND } 1 \\
\text { ISLAMIC BRAND } 2 \\
\text { ISLAMIC BRAND } 3\end{array}$ & $\begin{array}{l}0.984 \\
0.583\end{array}$ & 0.094 & 0.776 & 0.648 & 0.687 \\
\hline
\end{tabular}




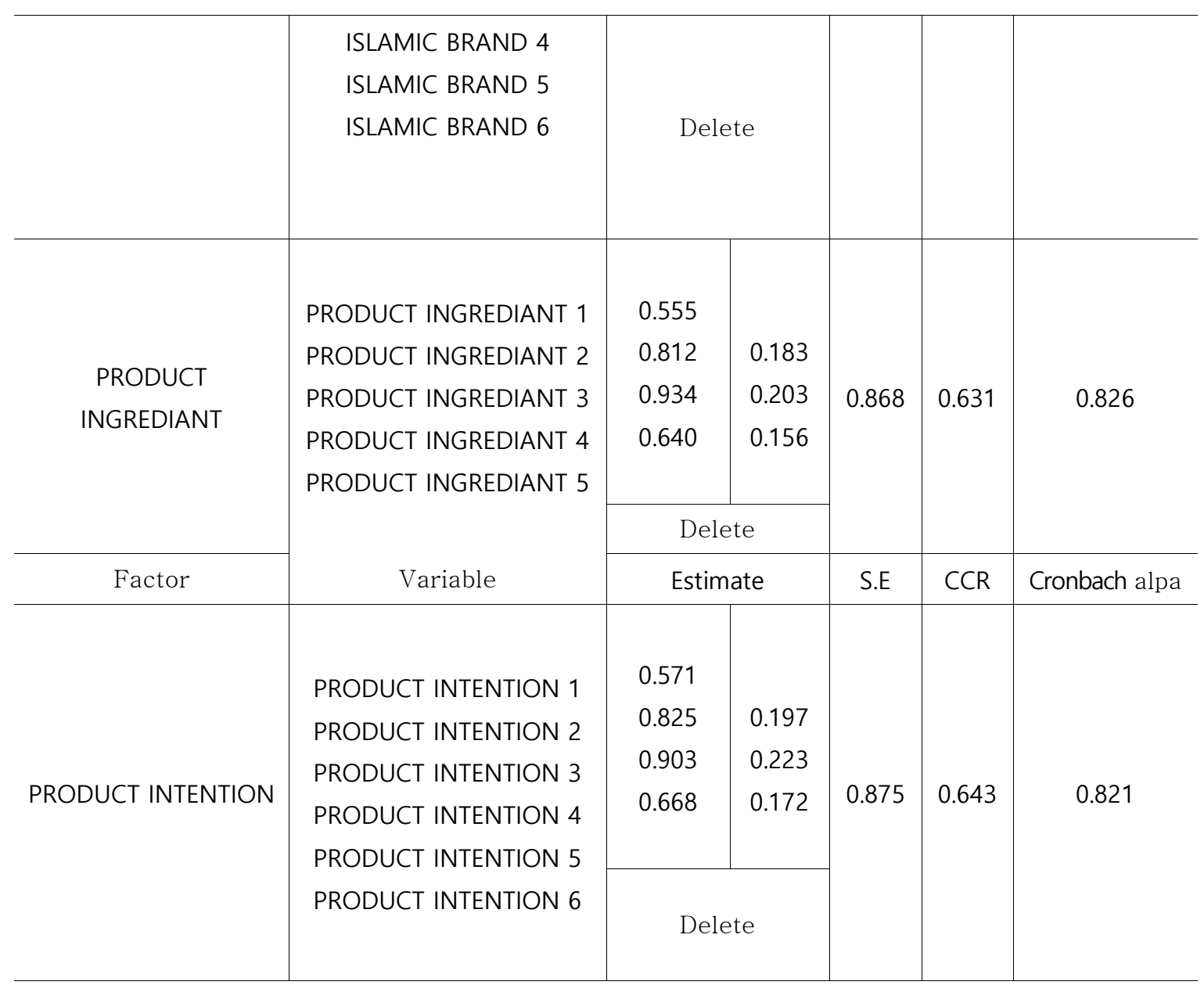

Goodness of fit: Chi-Squre $(x 2)=568.575, d f=345, x 2 / d f=1.648, p=0.000$,

$\mathrm{RMR}=0.051, \mathrm{NFI}=0.837, \mathrm{IFI}=0.929, \mathrm{TLI}=0.908, \mathrm{CFI}=0.927, \mathrm{RMSEA}=0.057$

Second, the standardization load of the construction concept is not satisfied with the reference value. RELIGIUOS BELIEFE 1, HALAL LOGO / CERTIFICATION 3, EXPOSURE 3, HALAL AWARENESS 3, HALAL AWARENESS 4, ISLAMIC BRAND 3, ISLAMIC BRAND 4, ISLAMIC BRAND 5, ISLAMIC BRAND 6 , PRODUCT INGREDIANT 5, PRODUCT INTENTION 5, and PRODUCT INTENTION 6 factors were deleted.

As a result of the final analysis except the deleted items, the standardized load value of construction concept was $0.448 \sim 0.998$, which was over 0.4 . The conceptual reliability (CCR) was calculated as follows: AWARENESS OF KOREA 0.854, RELIGIUOS BELIEEF 0.845, HALAL LOGO / CERTIFICATION 0.768, EXPOSURE 0.863, COO CREDIBILTY OF 
HALAL LOGO 0.789, HALAL AWARENESS 0.839, ISLAMIC BRAND 0.776, PRODUCT INGREDIANT 0.868, PRODUCT INTEGRITY 0.875 More than 0.7.

The mean variance extraction value (AVE) of the constructs was 0.500 for each factor, 0.659 for RELIGIUOS BELIEEFE, 0.659 for HALAL LOGO / CERTIFICATION, 0.690 for EXPOSURE, 0.50 for CEL CILIBILTY OF HALAL LOGO, 0.726 for HALAL AWARENESS, 0.648 for ISLAMIC BRAND, 0.648 for PRODUCT INGREDIANT, PRODUCT INTENTION 0.643, both exceeding 0.5. The standardization factor, the conceptual reliability, and the mean variance extraction value all exceeded the reference value, indicating that the central validity is satisfied.

Pearson correlation analysis

Correlation matrix and discriminant validity analysis result

\begin{tabular}{|c|c|c|c|c|c|c|c|c|c|}
\hline & (3) & (2) & (3) & (4) & (5) & (6) & (7) & (8) & (9) \\
\hline (1) & 1 & & & & & & & & \\
\hline (2) & $\begin{array}{l}0.199 * * \\
(0.040)\end{array}$ & 1 & & & & & & & \\
\hline (3) & $\begin{array}{c}0.004 \\
(0.000)\end{array}$ & $\begin{array}{l}0.327^{* *} \\
(0.107)\end{array}$ & 1 & & & & & & \\
\hline (4) & $\begin{array}{l}0.151^{*} \\
(0.006)\end{array}$ & $\begin{array}{l}0.151^{*} \\
(0.023)\end{array}$ & $\begin{array}{l}0.177^{*} \\
(0.031)\end{array}$ & 1 & & & & & \\
\hline (5) & $\begin{array}{l}0.230^{* *} \\
(0.053)\end{array}$ & $\begin{array}{l}0.227^{* *} \\
(0.052)\end{array}$ & $\begin{array}{l}.218^{* *} \\
(0.048)\end{array}$ & $\begin{array}{l}0.189 * * \\
(0.036)\end{array}$ & 1 & & & & \\
\hline (6) & $\begin{array}{c}-0.185^{\star \star} \\
(0.034)\end{array}$ & $\begin{array}{l}0.138^{*} \\
(0.019)\end{array}$ & $\begin{array}{l}0.143^{*} \\
(0.001)\end{array}$ & $\begin{array}{l}0.142 * \\
(0.020)\end{array}$ & $\begin{array}{l}-0.055 \\
(0.003)\end{array}$ & 1 & & & \\
\hline (7) & $\begin{array}{l}.0676 * \star \\
(0.457)\end{array}$ & $\begin{array}{l}0.367^{* *} \\
(0.135)\end{array}$ & $\begin{array}{l}0.160^{\star} \\
(0.010)\end{array}$ & $\begin{array}{c}0.037 \\
(0.001)\end{array}$ & $\begin{array}{l}0.193^{* *} \\
(0.009)\end{array}$ & $\begin{array}{c}0.016 \\
(0.000)\end{array}$ & 1 & & \\
\hline (8) & $\begin{array}{l}0.143^{*} \\
(0.000)\end{array}$ & $\begin{array}{l}0.150 * \\
(0.023)\end{array}$ & $\begin{array}{l}-0.009 \\
(0.000)\end{array}$ & $\begin{array}{l}0.217^{* *} \\
(0.047)\end{array}$ & $\begin{array}{l}0.182^{* *} \\
(0.001)\end{array}$ & $\begin{array}{l}0.217^{* *} \\
(0.047)\end{array}$ & $\begin{array}{l}0.178^{*} \\
(0.012)\end{array}$ & 1 & \\
\hline
\end{tabular}




\begin{tabular}{c|c|c|c|c|c|c|c|c|c}
\hline (9) & $\begin{array}{c}0.011 \\
(0.000)\end{array}$ & $\begin{array}{c}0.268^{* *} \\
(0.072)\end{array}$ & $\begin{array}{c}-0.135^{\star} \\
(0.001)\end{array}$ & $\begin{array}{c}0.112 \\
(0.013)\end{array}$ & $\begin{array}{c}0.139^{*} \\
(0.019)\end{array}$ & $\begin{array}{c}0.168^{*} \\
(0.012)\end{array}$ & $\begin{array}{c}0.189^{* *} \\
(0.036)\end{array}$ & $\begin{array}{c}0.222^{* *} \\
(0.049)\end{array}$ & 1 \\
\hline AVE & 0.500 & 0.659 & 0.539 & 0.690 & 0.58 & 0.726 & 0.648 & 0.631 & 0.643 \\
\hline
\end{tabular}

Analysis of structural model and hypothesis verification

1. Awareness of Korea appeared to have a positive effect on COO credibility of Halal logo ( $\beta$ $=0.188, \mathrm{t}=1.967, \mathrm{p}=0.049)$. Research hypothesis $\mathrm{H} 1$ was adopted.

2. Religious belief has a positive effect on COO credibility of Halal $\operatorname{logo}(\beta=0.201, t=$ $2.040, \mathrm{p}=0.041)$. Hypothesis H2a was adopted.

3. However, religious belief did not appear to have a significant effect on Halal awareness ( $\beta$ $=0.118, \mathrm{t}=1.465, \mathrm{p}=0.143)$. H2b was rejected.

4. Halal logo/certification did not show significant influence on Halal awareness $(\beta=-0.007$, $\mathrm{t}=-0.096, \mathrm{p}=0.923)$. H3 was rejected.

5. Exposure also showed no significant effect on Halal awareness $(\beta=0.042, t=0.727, p=$ 0.467). $\mathrm{H} 4$ was also rejected.

6. COO credibility of Halal logo appeared to have a positive effect on product intention ( $\beta=$ $0.169, \mathrm{t}=2.201, \mathrm{p}=0.028$ ).

7. Halal awareness appeared to have a positive effect on product intention $(\beta=0.137, t=$ $2.370, \mathrm{p}=0.018$ ).

8. Islamic brand did not have a significant effect on product intention $(\beta=0.082, \mathrm{t}=1.136, \mathrm{p}$ $=0.256)$. $\mathrm{H} 7$ was rejected.

9. Product ingredient appeared to have a positive effect on product intention $(\beta=0.182, \mathrm{t}=$ $2.393, \mathrm{p}=0.017)$.

Based on the analysis result, hypothesis verification result is as follows.

The model can be expressed as follows. 


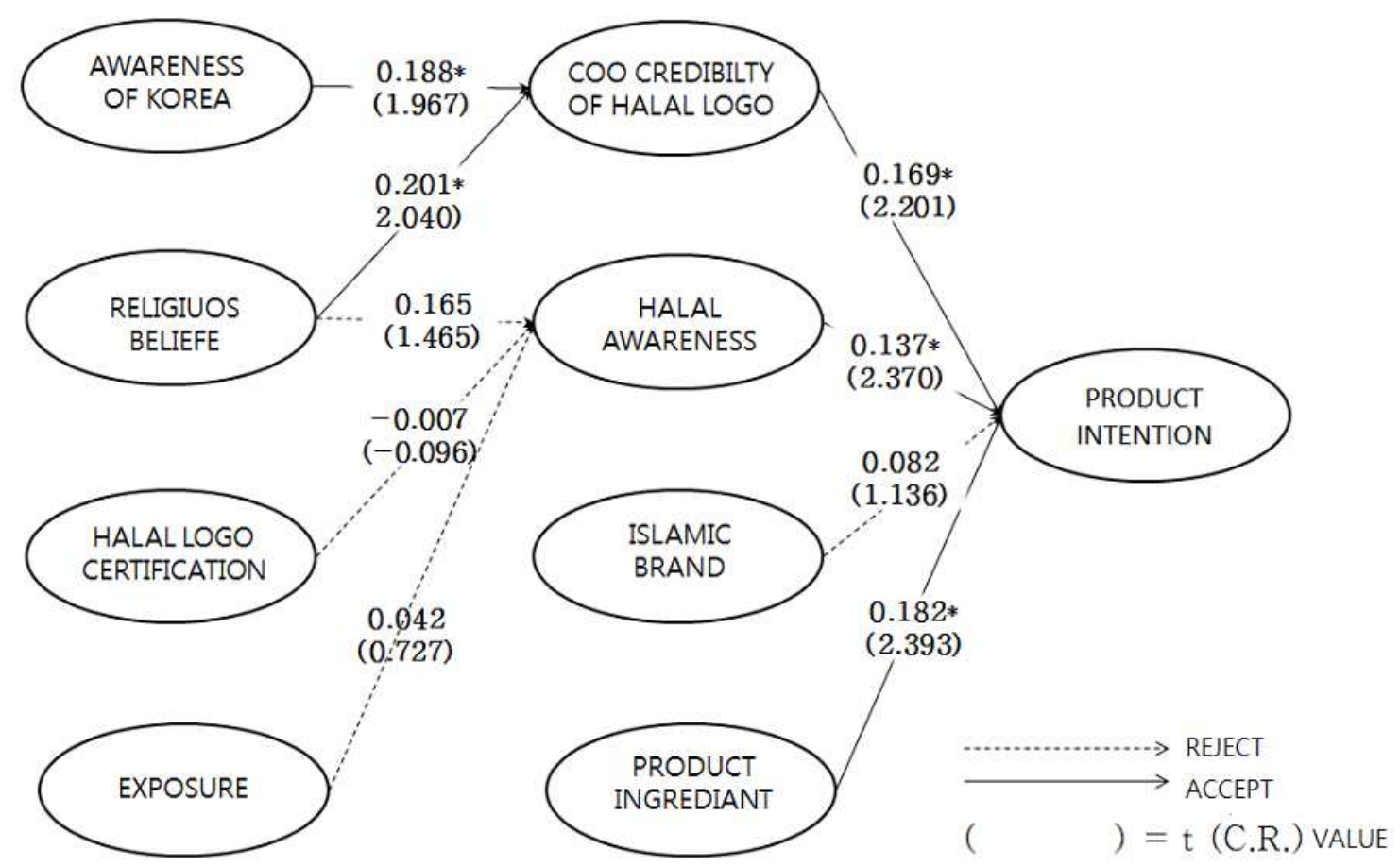

\section{CONCLUSION AND SUGGESTION}

\subsection{Conclusion}

The purpose of this study is to analyze how Indonesian Muslim consumers affect the purchasing of food and how Korean companies have a marketing strategy suitable for their consumption behavior in exporting food to Indonesia have. As a result of the study, we were able to get the following conclusions.

1. If understanding and religious faith in Korea is high, the reliability of halal certified foods produced in Korea can be enhanced. This indicates that understanding of Korea will eventually affect the credibility of the country of origin and that the higher the confidence in the country of origin, the more reliable the halal certification in that country. Also, consumers with high religious values tend to check the Halal accreditation in imported foods, and they tend to consider the reliability of 
country of origin. The results of this study are consistent with the assertion of Schiffman and Kanuks (1997). Purchasing decisions of members of other religious groups are influenced by religious identity, direction, knowledge and beliefs. Ultimately, the credibility of the country of origin will ultimately increase the purchasing intentions of Indonesian consumers, so it is concluded that a high level of understanding and faith in Korea can lead to an increase in sales.

2. The higher the level of understanding about Halal, the higher the intention to purchase Halal food. This is not a religious instruction to simply eat only Halal foods, but it includes practical aspects such as understanding of origins and reasons, types and methods. These results show that a good attenuation of Halal has a positive effect on the intention to purchase Halal products. In other words, it can be seen that consumers who have a high level of understanding about Halal may increase their purchase of Halal products. These results are the same as those of the previous study by Afshan Azam (2016).

3. Food components have the highest positive impact on food purchasing. This is because the division of the halal is not simply a color or a shape but an inner raw material. As a result, food ingredients and ingredients must be clearly marked on the outside, which is expected to result in increased sales for Muslim consumers by positively impacting their consumption and purchasing behavior. These results are the same as those of the previous study by Afshan Azam (2016). In the previous study, it was considered that the relationship between product component and purchase intention was important, and therefore, it was claimed that product component gave important value to consumers' purchase behavior(Abdul 2013) 


\section{References}

[1] Afshan, "Azam, (2016) "An empirical study on non-Muslim's packaged halal food manufacturers: Saudi Arabian consumers' purchase intention", Journal of Islamic Marketing, Vol. 7 Issue: 4," pp. 441-460.

[2] Abdul, "L.Z.A., Mohamed, Z.A., Rezai, G. and Kamaruzzaman, N.H. (2013), 'The impact of food labeling on purchasing behavior among non-Muslim consumers in Klang Valley',."

[3] Australian, "Journal of Basic and Applied Sciences, Vol. 7 No. 1, pp. 124-128. Ajzen, I. (1985), 'From intentions to actions: a theory of planned behavior', in Kuhl, J. and Beckmann, J. (Eds),."

[4] Action, "Control: From Cognition to Behavior, Springer, Heidelberg.," pp. 11-39.

[5] Ajzen, “,I.(1991), 'Thetheoryofplannedbehavior’,OrganizationalBehaviorandHumanDecision Processes,Vol.50No.2.,” pp. 179-211.

[6] Alam, "S.S.andSayuti,N.M.(2011), Applyingthetheoryofplannedbehavior(TPB)inhalalfood purchasing',InternationalJournalofCommerceandManagement, Vol. 21 No. 1.,” pp. 8-12.

[7] Alserhan, "B.A.(2010), 'Islamicbranding:aconceptualizationofrelatedterms',JournalofBrand Management,Vol.18No.2.,” pp. 34-39.

[8] Andersen, "E.S. (1994), 'The evolution of credence goods: a transaction approach to product specification and quality control', MAPP working paper No. 21, The."

[9] Ardayanti, “A., Nashril, T.T.A. and Helmi, A. (2013), 'A study on halal food awareness among Muslim Customers in Klang Valley', 4th International Conference on Business and EconomicResearchpaper1,073,Bandung."

[10] Aziz,

"Y.A.andVui,C.N.(2012),'TheroleofhalalawarenessandhalalcertificationininfluencingnonMusli m'spurchaseintention',3rdInternationalConferenceonBusinessandEconomic Research (3rd ICBER 2012) Proceedings paper 1,819, Bandung."

[11] A. Aziz, "Y. and Chok, N.V. (2012), 'The role of halal awareness, halal certification, and marketing components in determining halal purchase intention among non-Muslims in Malaysia: a structural equation modelling approach', Journal of International Food \& Agribusi," pp. 1-23.

[12] Ajzen, "I. (1991), 'The theory of planned behaviour', Organizational Behavior and Human Decision Process, Vol.50No.2.," pp. 179-211.

[13] Akdeniz, “, B., Calantone, R.J. and Voorhees, C.M. (2013), 'Effectiveness of marketing cues on consumer perceptions of quality: the moderating roles of brand reputation and third-party information', Psychology\&Marketing,Vol.30No.1.," pp. 76-89.

[14] Akin, “A.,Turan,M.E.andAltundag,Y.(2015), 'The validity and reliability of Turkish version of Santa Clara strength of religious faith questionnaire', Journal of Educational \& Instructional Studiesin theWorld,Vol.5No.1,pp.35-38. Al-Qardawi, Y. (2001), The Lawful a."

[15] Andéhn,

"M.,Nordin,F.andNilsson,M.E.(2016), 'Facetsofcountryimageandbrandequity:revisiting the role of product categories in country-oforigin effect research', Journal of Consumer."

[16] "Beards worth \& Keil, 2002; Fischler, 1988, Food habits, social change and the nature/culture dilemma."

[17] Behaviour, “,Vol.15No.3,pp.225-238,availableat:https://doi.org/10.1002/cb.1550 Armitage, C.J. and Conner, M. (2001), 'Efficacy of the theory of planned behaviour: a meta-analytic 
review',The British Journal of Social Psychology,Vol.40No.3.”

[18] Bilkey, "W.J. and Nes, E. (1982), 'Country of origin effects on product evaluation', Journal of InternationalBusinessStudies, Vol.13No.1.," pp. 89-99.

[19] Bonne, "K. and Verbeke, W. (2008), 'Muslim consumer trust in halal meat status and control in Belgium', Meat Science, Vol. 79 No. 1.," pp. 113-123.

[20] CAP, “'Panduan Persatuan Pengguna Pulau Pinang: Halal Haram', Persatuan Pengguna PulauPinang."

[21] J. (1992. Cohen, ““Apowerprimer',PsychologicalBulletin,Vol.112No.1.,” pp. 155-159.

[22] V. V. (1991) Cordell, “'Competitive context and price as moderators of country of origin preferences', JournaloftheAcademyofMarketingScience,Vol.19No.2.,” pp. 123-128.

[23] M. Y. Che, . "and Sazili, A.Q. (2010), 'Food production from the halal perspective', in Guerrero-Legarreta, I., Alarcón-Rojo, A.D., Hui, Y.H. and Alvarado, C. (Eds), Handbook of Poultry Science and Technology, A John Wiley \& Sons, Hoboken, NJ.,” pp. 183-216.

[24] W. . Chin, “andGopal,A.(1995),'AdoptionintentioninGSS:relativeimportanceofbeliefs',ACM SigMIS Database, Vol. 26 Nos 2/3.," pp. 42-64.

[25] W. . Chin, "Marcolin, B.L. and Newsted, P.R. (2003), 'A partial least squares latent approachformeasuringinteractioneffects:resultsfromaMonteCarlosimulation study and an electronic-mail emotion/adoption study', Information Systems Research, Vol.14No.2.," pp. 189-217.

[26] T. . Cook, “Campbell,D.T.andDay,A.(1979),Quasiexperimentation:DesignandAnalysisIssues for Field Settings, Houghton Mifflin, Boston, MA."

[27] M. A. . Davies, “andWright,L.T.(1994),'Theimportanceoflabelingexaminedinfoodmarketing', European Journal of Marketing, Vol. 28 No. 2.," pp. 57-67.

[28] " 1 . Does the country of origin of a halal logomatter? The case of packaged food purchases Nazlida Muhamadand Vai Shiem Leong UBD School of Business and Economics, Universiti Brunei Darussalam, Gadong, Brunei Darussalam, and Normalisa MdIsa Department of Ma.”

[29] M. . Delgado-Guay, .“, Chisholm, G., Williams, J. and Bruera, E. (2015), 'The association between religiosity and resuscitation status preference among patients with advanced cancer', Palliative andSupportiveCare,Vol.13No.5.," pp. 1435-1439.

[30] E.

Dimara, ."andSkuras,D.(2003), 'Consumerevaluationofproductcertification, geographicassociatio nandtraceabilityinGreece',EuropeanJournalofMarketing,Vol.37Nos5/6,pp..andSkuras,D.(2003), "Consumerevaluationofproductcertification,geographicassociationandtraceabilityinGreece," pp. 690-705.

[31] Falk, "R.F.andMiller,N.B.(1992),APrimerforSoftModeling,UniversityofAkronPress,Akron, OH. Fishbein, M. and Ajzen, I. (2005), 'Theory-based behavior change interventions: comments on Hobbis and Sutton', Journal of Health Psychology, Vol. 10 No. 1, pp.,” pp. 27-31.

[32] Fazio, "R.H. (1990), 'Multiple processes by which attitudes guide behavior: the mode model as an integrative framework', Advances in Experimental Social Psychology, Vol. 23, pp. 75-109, availableat:https://doi.org/10.1016/S0065-2601(08)60318-4."

[33] Felix, "R. and Braunsberger, K. (2016), 'I believe therefore I care: the relationship between religiosity, environmental attitudes, and green product purchase in Mexico', International Marketing Review,Vol.33No.1.," pp. 137-155.

[34] Fornell, “C.andLarcker,D.F.(1981),'Structuralequationmodelswithunobservablevariablesand measurement error: algebra and statistics', Journal of Marketing Research, Vol. 18 No. 3,” pp. 
382-388.

[35] Food, "Standards Autralia New Zealand, available at: www.foodstandards. gov.au(Accessed12December,2014)."

[36] Fokus, "2011, The latest trends in the world economy."

[37] Gefen, "D.andStraub,D.(2005), 'ApracticalguidetofactorialvalidityusingPLSGraph:Tutorial and annotated example', Communications of the Association for Information Systems, Vol.16No.5," pp. 91-109.

[38] Golnaz, "R., Zainal, A.M. and Nasir, M.S. (2012), 'Assessment of consumers: confidence on halal labeled manufactured food in Malaysia', Social, Science \& Humanities, Vol. 20 No. 1,” pp. $33-42$.

[39] Herath, “T.and Rao,H.R.(2009),'Protection motivation and deterrence: a frame work for security policy compliance in organizations', European Journal of Information Systems, Vol. 18 No.2,pp.106-125. Hrubes, D., Ajzen, I. and Daigle, J. (2001), "Predicting hunting," pp. 165-178.

[40] Hussaini,

“M.M.(2004),'Halalharamlists:whytheydonotwork?',HalalandHealthy,availableat:www.soundvi sion.com/info/halalhealthy/halal.list.asp(accessed9October2014).”

[41] Hair, "J.F., Hult, G.T.M., Ringler, C. and Starstedt, M. (2014), A Primer on Partial Least Squares Structural Equation Modelling (PLS-SEM), SAGE Publications, Thousand Oaks, CA."

[42] Harrison-Dunn, “A. (2014), "Self-certification of halal products "rife" in Britain: halal foundation', available at: www.foodnavigator.com/Market-Trends/Self-certification-of-halalproducts-rife-inBritain-Halal-Foundation (accessed 13 October 2016)."

[43] Henseler, "J.,Ringle, C.M. and Sinkovics, R.R. (2009), 'The use of partiall easts quares path modeling in international marketing', New Challenges to International Marketing, Advancesin International Marketing, Emerald Group Publishing Limited, Vol.20,pp.277-319, a."

[44] Halal, “,Zawya,Dubai,pp.1-5. Wilson, J.A.J. and Liu, J. (2010), 'The shaping the halal into a brand?', Journal of Islamic Marketing,Vol.1No.2,pp.107-123. Wilson, J.A.J. and Liu, J. (2011), 'The challenges of Islamic branding: navigating emotions and halal', Journ," pp. $28-42$.

[45] Hassan, "S.H. (2014), 'The role of Islamic values on green purchase intention', Journal of Islamic Marketing,Vol.5No.3,pp.379-395. Hayes, A.F. (2013), Introduction to Mediation, Moderation, and Conditional Process Analysis: A Regression-BasedApproach,GuilfordPress.”

[46] Hofstede, “,G.(1991),CulturesandOrganisation;SoftwareoftheMind,Mc-GrawHill1,London.”

[47] Johansson, "J.K. (2014), "Missing a strategic opportunity: managers' denial of country-of-origin effects", in Papadopoulos, N. and Heslop, L.A. (Eds), Product-Country Images: Impact and Role in International Marketing, 2nded., The Haworth press, NewYork,NY,pp.77-86."

[48] Korea, “Trade Investment Promotion Agency's 2010, Korea's entry into the Islamic market and its vision."

[49] Kline, "R.B.(1998),PrinciplesandPracticesofStructuralEquationModeling,3rded.,Adivisionof Guilford publication, Guilford, NewYork,NY. Kotler, P. and Armstrong, G. (2004), Principles of Marketing, 10th ed.,."

[50] Khare, “A., Mukerjee, S. and Goyal, T. (2013), 'Social influence and green marketing: an exploratory study on Indian consumers', Journal of Customer Behaviour, Vol. 12No. 4, pp.," pp. $361-381$.

[51] Lever, "J. and Miele, M. (2012), 'The growth of halal meat markets in Europe: an exploration of the supply side theory of religion', Journal of Rural Studies, Vol.28No.4,” pp. 528-537.

[52] Lim, "K.H., Hu, W., Maynard, L.J. and Goddard, E. (2014), 'A taste of beef? How much does 
consumers perceived risk influence willingness to pay for country-of-origin labeled beef', Agribusiness, Vol.30No.1,pp.17-30."

[53] Loch, "K., Straub, D. and Kamel, S. (2003), 'Diffusing the internet in the Arab world: the role of social norms and technological culturation', IEEE Transactions on Engineering Management,Vol.50No.1,pp.45-63."

[54] MAFF, “(1986), 'Surveyofconsumerattitudestofoodadditives',MinistryofAgriculture,Fisheries, and Foods, HMSO, London."

[55] Micheal, “C.D.(2015), 'Globalhalalfoodmarketnowworth\$1.1trillion',HalalExpoEurope,15-16 April, available at:www.halalexpoeurope.eu/global-halal-food-market-now-worth-11trillion/?langen(accessed5May2015)."

[56] Morrow, “J.L.Jr.,Hansen,M.H.andPearson,A.W.(2004),'Thecognitiveandaffectiveantecedents of general trust within cooperative organizations', Journal of Managerial Issues, Vol. 16 No.1,pp.48-64."

[57] Metzger, "M.J.and Flanagin,A.J.(2013), "Credibility and trust of information in online environments : the use of cognitive heuristics', Journal of Pragmatics,Vol.59PartB,pp.210-220.”

[58] Mohd, "Hussain, N.A.(2010), JAISHaramkan Sijil, Logo Halal Syarikat Swasta, availableat: www.mstar. com.my/berita/berita-semasa/2010/03/06/jais-haramkan-sijil-logo-halal-syarikatswasta/."

[59] Moulard, “, J. and Babin, B.J. (2015), "How aspects of a wine's place affect consumers' authenticity perceptions and purchase intentions", International Journal of Wine Business Research, Vol. 27 No.1,pp.61-78."

[60] Muhamad, "N. and Mizerski, D. (2010), "Exploring Muslim consumers' information sources for fatwa rulings on products and behaviors", Journal of Islamic Marketing, Vol. 1 No. 1, pp. 37-50."

[61] N. Muhamad, "and Dahari, Z. (2010), 'halal concept comprehension and importance of packaging elements among Muslim consumers', International Conference on Islamic Marketing and Branding, University Malaya, Kuala Lumpur."

[62] D. Muhamad, N. and Mizerski, “(2013), 'The effects of following Islam in decisions about taboo products',Psychology\&Marketing,Vol.30No.4,pp.357-371.”

[63] V. S. and M. Muhamad, N., Leong, "D. (2016), 'Consumer knowledge and religious rulings on products: young Muslim consumer's perspective', Journal of Islamic Marketing, Vol. 7 No. 1, pp.7494,availableat:https://doi.org/10.1108/JIMA-08-2014-0056.”

[64] G. (2013) Muhamed, Z., Samsudin, M.N. and Rezai, “"The effect of possessing information about halal logo on consumer confidence in Malaysia', Journal of International Food \& Agribusiness Marketing,Vol.25No.1,pp.73-86."

[65] Nazahah, “A.R.andSutina,J.(2012), 'The halal product acceptance model for there ligioussociety', Business \& Management Quarterly Review, Vol. 3 No. 1, pp. 17-25.”

[66] Patnoad, "M.S. (2001), 'Food safety education in England: a report from the NEHA/CIEH sabbatical exchange program', Journal of Environmental Health, Vol. 3 No. 10, pp. 21-26.”

[67] Gayatri, “G., Hume, M. and Mort, G.S. (2011), 'The role of Islamic culture in service quality research', Asian Journal on Quality, Vol. 12 No. 1, pp. 35-53, available at: https://oi.org/10.1108/ 15982681111140534."

[68] Podsakoff,

"P.M.,MacKenzie,S.B.,Lee,J.Y.andPodsakoff,N.P.(2003), 'Commonmethodbiasesinbehavioralres earch:acriticalreviewoftheliteratureandrecommendedremedies',Journal of Applied Psychology, Vol. 88 No. 5, pp. 879-903." 
[69] Pew, "forum 2013,11, You need to know Islamic economy to know the world economy."

[70] Randolph, “G. (2003), 'Surgical anatomy of recurrent laryngeal nerve', in Randolph, G. (Ed.), Surgery of the Thyroid and Parathyroid Glands, Elsevier, New York, NY, pp. 300-343."

[71] Riaz, "M.N. and Chaudry, M.M. (2004), Halal Food Production, CRC Press, Boca Raton, FL.”

[72] Schiffman, “, L.G. and Kanuk, L.L. (1997), Consumer Behavior,6th ed., Prentice-Hall, Upper Saddle River,NJ."

[73] Sekaran, "U.(2005),ResearchMethodsforBusiness:ASkill-BuildingApproach,4thed.,."

[74] John, "NWiley andSons,NewYork,NY. Shafie, S. and Othman, M.N. (2006), 'Halal certification: international marketing issues and challenges', The IFSA Vii World Congress 2006 Proceedings, Berlin, pp. 1-11o Title."

[75] Straub, “D.W. (1989), 'Validating instruments in MIS research', MIS Quarterly, Vol. 13 No. 2, pp.147-169. Wandel, M. (1997), 'Food labeling from a consumer perspective', British Food Journal, Vol. 99 No.6,pp.212-219.”

[76] Wilson, "J.A.J.(2014a),IslamicEconomics2.0CreatingAHalalWealthandKnowledgeEconomy, Zawya,Dubai,pp.1-7. Wilson, J.A.J. (2014b), Revisiting the Philosophical Arguments Underpinning Islamic Financeand." 